\title{
Mellkasiaortastentgraft-beültetések Magyarországon 2012 és 2016 között
}

\author{
Fontanini Daniele Mariastefano dr. ${ }^{1}$ - Fazekas Gábor dr. ${ }^{2}$ \\ Vallus Gábor $\mathrm{dr}^{3}{ }^{3}$ - Juhász György dr. ${ }^{4}$ - Váradi Rita $\mathrm{dr} .^{5}$ \\ Kövesi Zsolt dr. ${ }^{6}$ - Kolossváry Márton dr. ${ }^{1}$ - Szeberin Zoltán dr. ${ }^{1}$ \\ ${ }^{1}$ Semmelweis Egyetem, Általános Orvostudományi Kar, Városmajori Szív- és Érgyógyászati Klinika, \\ Érsebészeti Tanszék, Budapest \\ ${ }^{2}$ Pécsi Tudományegyetem, Érsebészeti Klinika, Pécs \\ ${ }^{3}$ Magyar Honvédség Egészségügyi Központ, Budapest \\ ${ }^{4}$ Borsod-Abaúj-Zemplén Megyei Kórház és Egyetemi Oktató Kórház, Miskolc \\ ${ }^{5}$ Szegedi Tudományegyetem, Általános Orvostudományi Kar, Sebészeti Klinika, Szeged \\ ${ }^{6}$ Petz Aladár Megyei Oktató Kórház, Győr
}

\begin{abstract}
Napjainkban a világszerte elterjedt mellkasiaortastentgraft-beültetés hazánkban is egyre nagyobb teret nyer. Eddig a hazai tapasztalatokról átfogó beszámoló nem jelent meg. A módszer elterjedése folyamatban van, az eddigi eredmények elemzése a további kezelési stratégia optimális meghatározása céljából indokolt. A magyar mellkasi stentgraftmútétek perioperatív eredményeit elemeztük 5 év tapasztalatai alapján. Retrospektív, multicentrikus tanulmányunk keretében adatokat gyüjtöttünk Magyarország minden mellkasi stentgraft-implantációt végző intézményéből. Az adatok jelentése önkéntes volt, 5 év mellkasi aortát érintő stentgraftbeültetési adatait összesítettük. Magyarországon 2012 és 2016 között 131 mellkasiaortastentgraft-beültetést végeztek. A férfiak aránya 67,18\%, a betegek átlagéletkora 62,80 év volt. Az elvégzett beavatkozás az esetek 25,19\%-ában volt sürgető. A betegek kórelőzményében 13,74\%ban szerepelt cukorbetegség. A beavatkozást az esetek 64,89\%-ában aneurysma, 17,56\%-ában dissectio, 6,87\%-ában traumás aortasérülés és 10,69\%-ában egyéb betegség indikálta. Az aortadissectiós esetek 73,91\%-ban akutak voltak. Aneurysma miatt 16,47\%-ban történt akut beavatkozás ruptura miatt. A stentgraftbeültetések 26,72\%-ában végeztek kiegészítő revascularisatiós mütétet a supraaorticus ágakon (debranching). A posztoperatív időszakban az esetek 4,58\%-ában alakult ki stroke, 1,53\%-ában volt szükség átmeneti vesepótló kezelésre, és 2,29\%-ában alakult ki bélischaemia. Harminc napon belüli reoperációra 5,34\%-ban volt szükség. A mútétek 30 napos mortalitása 9,92\% volt, az 5 éves utánkövetés során bekövetkezett hosszú távú halálozás 16,03\%-ot ért el. A mellkasi aorta stentgrafttal történő endovascularis helyreállító mútétje hatékony eljárás, előnyei egyértelműek a hazai adatok alapján is a nyitott mellkasi mútétekkel szemben. További hazai elterjedése a centralizált érsebészeti ellátás kialakításának és a megfelelő finanszírozásnak a függvénye. Az optimális kezelés biztosításához elengedhetetlen a társszakmák jelenléte és a megfelelő logisztika biztosítása.
\end{abstract}

Orv Hetil. 2018; 159(2): 53-57.

Kulcsszavak: mellkasi aorta, endovascularis, stentgraft, adatbázis

\section{Thoracic aortic stentgraft implantations in Hungary from 2012 to 2016}

Thoracic aortic endograft implantation has become a widespread procedure in recent years, yet no report is available about Hungarian outcomes. Examination of our results is crucial to define further treatment strategies. Analysis of perioperative data from Hungarian thoracic endograft implantations based on the experience of 5 years is presented. Our retrospective, multicentric study analysed voluntarily reported data from all Hungarian institutions where thoracic endograft implantations are performed. Information was collected from every procedure performed in 5 years. Between 2012 and 2016, 131 thoracic stent graft implantations were performed in Hungary $(67.18 \%$ male, mean age 62.80 years). $25.19 \%$ of the procedures were acute. $13.74 \%$ of the patients were diabetic. Indications for the procedure were aneurysm $(64.89 \%)$, dissection $(17.56 \%)$, aortic trauma $(6.87 \%)$ and other conditions $(10.69 \%)$. $73.91 \%$ of the dissection cases were acute. $16.47 \%$ of repaired aneurysms were ruptured. Additional preoperative revascularization (debranching) was performed in $26.72 \%$ of the cases. Postoperative stroke occured in $4.58 \%$, temporary hemodialysis was needed in $1.53 \%$, bowel ischaemia was present in $2.29 \%$ and reoperation within 30 days was 
needed in $5.34 \%$ of all cases. Thirty-day mortality of the procedure was $9.92 \%, 5$-year long-term mortality reached $16.03 \%$. Endovascular repair of the thoracic aorta is an effective procedure and our national data comfirmed its advantages compared to open thoracic surgery. Further use of the procedure in Hungary depends on the centralised care in vascular surgery and financial matters. Multidisciplinary cooperation and proper logistics are needed to provide patients with optimal treatment.

Keywords: thoracic aorta, endovascular, stent graft, database

Fontanini DM, Fazekas G, Vallus G, Juhász Gy, Váradi R, Kövesi Zs, Kolossváry M, Szeberin Z. [Thoracic aortic stentgraft implantations in Hungary from 2012 to 2016]. Orv Hetil. 2018; 159(2): 53-57.

(Beérkezett: 2017. október 9.; elfogadva: 2017. november 9.)

\begin{abstract}
Rövidítések
ESVS = European Society for Vascular Surgery (Európai Érsebészeti Társaság); MAÉT = Magyar Angiológiai és Érsebészeti Társaság; PTE = Pécsi Tudományegyetem; SD = standard deviáció; SZTE = Szegedi Tudományegyetem; TEVAR = thoracic endovascular aortic repair (mellkasi endovascularis aortarekonstrukció); ThAA = thoracic aortic aneurysm (mellkasiaorta-aneurysma)
\end{abstract}

A mellkasi aorta stentgrafttal történő helyreállító mútétje (thoracic endovascular aortic repair, TEVAR) világszerte elterjedőben lévő eljárás, mely a kifejlesztése óta új távlatokat nyitott a mellkasi aorta betegségeinek korszerủ kezelésében $[1,2]$. A betegellátás invazivitását minimálisra csökkentő módszer lehetôvé teszi, hogy az aorta mútéti helyreállítása megoldást jelentsen olyan esetekben is, amelyekben a nyitott sebészi beavatkozás kivitelezhetetlen volna [3]. Ennek fényében a TEVAR Magyarországon is egyre szélesebb körben alkalmazott eljárás, a módszer alkalmazásával szerzett hazai tapasztalatokról azonban mindeddig nem jelent meg átfogó beszámoló. A Magyar Angiológiai és Érsebészeti Társaság (MAÉT) Érsebészeti Regisztere alapján készült, 2015-ben az Orvosi Hetilap hasábjain publikált tanulmány beszámolt az infrarenalis aortaaneurysmák magyarországi ellátásának részleteirôl $[4,5]$. Célkitűzésünk az volt, hogy ehhez hasonlóan a hazánkban végzett TEVAR-mútétek 5 éves perioperatív adatait felhasználva országos adatbázist hozzunk létre, mely tapasztalatok összessége a jövőben lehetővé teszi a betegek kezelésének optimalizálását.

\section{Módszer}

Retrospektív, multicentikus tanulmányunk során adatgyújtést végeztünk minden olyan magyarországi intézményt bevonva, ahol 2012. 01. 01. és 2016. 12. 31. között mellkasiaortastentgraft-beültetést végeztek. A Semmelweis Egyetem Városmajori Szív- és Érgyógyászati Klinikájának összegyújtött és rendszerezett adatait ezáltal a budapesti Magyar Honvédség Egészségügyi Központ, a PTE Érsebészeti Klinika, az SZTE Sebészeti Klinika, a miskolci Borsod-Abaúj-Zemplén Megyei Kór- ház és Egyetemi Oktató Kórház, valamint a gyơri Petz Aladár Megyei Oktató Kórház által önkéntesen szolgáltatott adatok felhasználásával országos adatbázissá alakítottuk, amelyben szerepel az említett 5 éves időintervallumban hazánkban végzett összes mellkasi stentgraftbeültetés. Statisztikai elemzésünk során KaplanMeier-próbát alkalmaztunk IBM SPSS Statistics 23.0 szoftver felhasználásával (IBM Corporation, Armonk, NY, USA). Vizsgálatunkat a személyes adatok védelméről és közérdekú adatok nyilvánosságáról szóló hatályos törvények figyelembevételével, a Semmelweis Egyetem Regionális, Intézményi Tudományos és Kutatásetikai Bizottsága által rendelkezésünkre bocsátott, 92/2017. számú etikai engedély birtokában vittük véghez. Személyazonosításra alkalmas egészségügyi adatok nem kerültek feldolgozásra.

\section{Eredmények}

Hazánkban 2012. 01. 01. és 2016. 12. 31. között összesen 131 esetben végeztek mellkasi stentgraftbeültetést. A Semmelweis Egyetem Városmajori Szív- és Érgyógyászati Klinikáján 57, a PTE Érsebészeti Klinikán 25, a Magyar Honvédség Egészségügyi Központban 24, a miskolci Borsod-Abaúj-Zemplén Megyei Kórház és Egyetemi Oktató Kórházban 13, az SZTE Sebészeti Klinikán 7, a győri Petz Aladár Megyei Oktató Kórházban 5 mútétet végeztek. A beavatkozáson átesett betegek átlagos életkora $62,80( \pm 15,3 \mathrm{SD})$ év volt. Nemek szerinti eloszlás: az esetek $67,18 \%$-ában férfi betegen végezték az implantációt. A cukorbetegek aránya $13,74 \%$ volt. A TEVAR az esetek 25,19\%-ában akut, míg 74,81\%-ában elektív intervenció volt. A beavatkozások javallata tekintetében a TEVAR-t igénylő kórképek között a mellkasiaorta-aneurysma (ThAA) volt a leggyakoribb: $64,89 \%$. A TEVAR-ral kezelt ThAA-k közül az esetek 16,47\%ában az aneurysma rupturája állt fent. A Stanford B típusú aortadissectio volt a második leggyakoribb betegség, mely a TEVAR-mútétek 17,56\%-át indikálta. Ennél a kórképnél az akut beavatkozások aránya $73,91 \%$ volt. Az összes eset 6,87\%-ában az implantáció javallata tompa mellkasiaorta-sérülés volt, míg a maradék 10,69\%-ban egyéb okból volt szükség mellkasiaortastentgraft-beülte- 


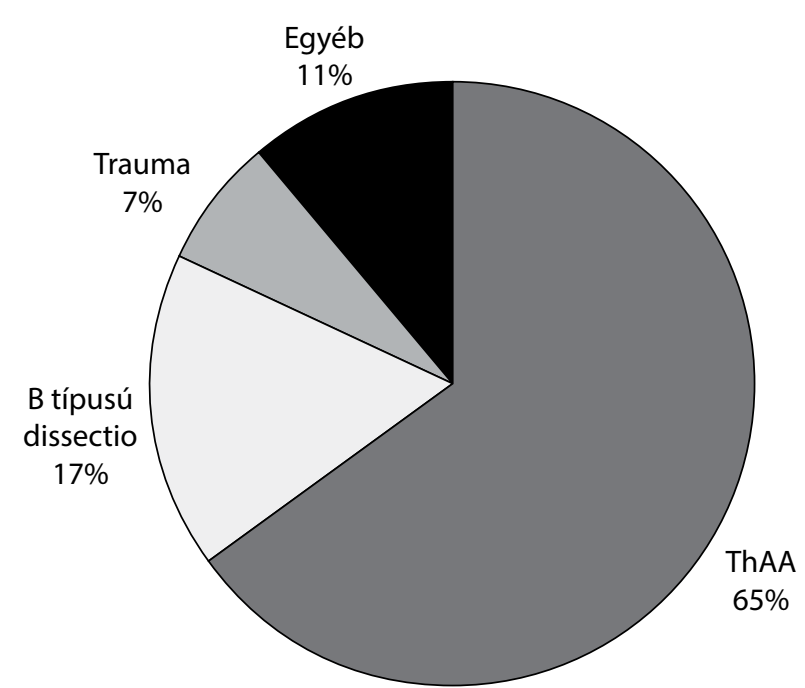

1. ábra $\quad$ A hazai mellkasiaortastentgraft-implantációk indikáció szerint megoszlása 2012 és 2016 között

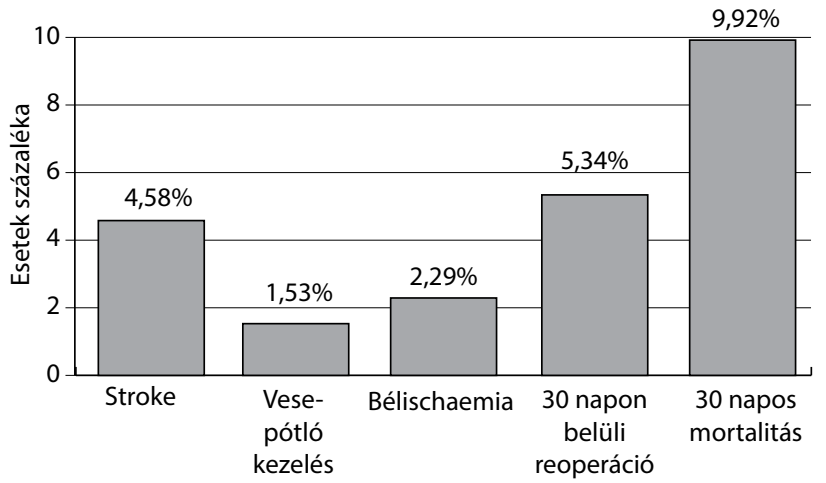

2. ábra | Posztoperatív szövődmények

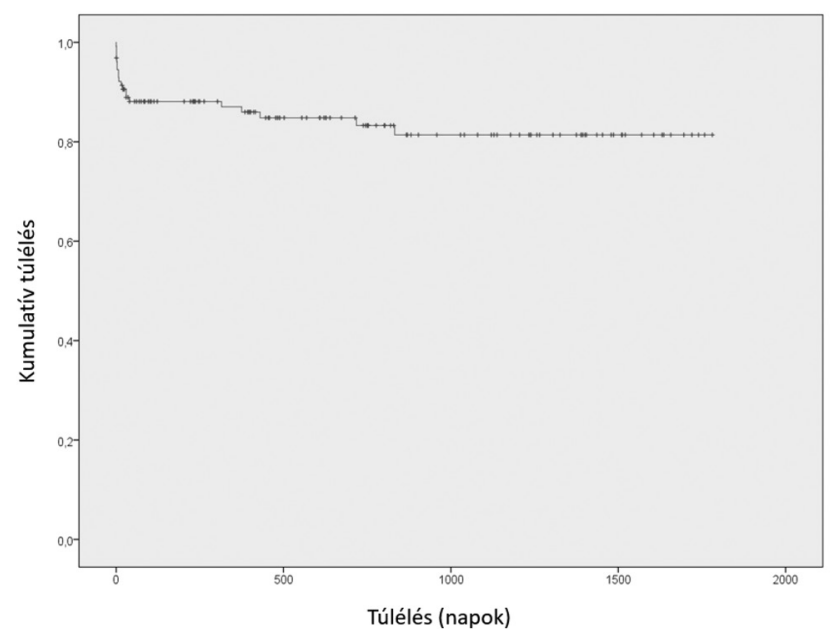

3. ábra $\quad$ A hosszú távú halálozás 5 év utánkövetés során

tésre (posztoperatív endoleak, plakkruptura, intramuralis haematoma) (1. ábra). A stentgraftbeültetések 26,72\%ában végeztek kiegészítő mútétet a supraaorticus ágakon (debranching). A korai posztoperatív időszakban TEVAR után 4,58\%-ban következett be stroke, a posztoperatív intenzív terápia során átmeneti vesepótló kezelés az esetek 1,53\%-ában vált szükségessé, valamint 2,29\%-ban alakult ki a belek ischaemiája. A vizsgált időszakban bekövetkezett posztoperatív szövődmények aránya a 2. ábrán látható. Az elvégzett mellkasi stentgraft-implantációkat követően 30 napon belül 5,34\%-ban vált szükségessé a betegek reoperációja. A 30 napon belül bekövetkezett halálesetek aránya $9,92 \%$ volt. A rövid távú mortalitásnak az indikáció, valamint sürgősség szerinti eloszlását az 1. táblázat szemlélteti részletesen. A vizsgált 5 éves időintervallumban, mely alatt a betegek szoros utánkövetés alatt álltak, 16,03\%-os volt a hosszú távú mortalitás (3. ábra).

1. táblázat A 30 napos mortalitás eloszlása a beavatkozás indikációja és sürgőssége szerint

\begin{tabular}{lllll}
\hline & ThAA & $\begin{array}{l}\text { B típusú } \\
\text { dissectio }\end{array}$ & Trauma & Egyéb \\
\hline Akut & $3(33,33 \%)$ & $3(18,75 \%)$ & $2(28,57 \%)$ & $0(0 \%)$ \\
Elektív & $4(5,26 \%)$ & $0(0 \%)$ & $0(0 \%)$ & $1(7,69 \%)$ \\
\hline
\end{tabular}

ThAA $=$ thoracic aortic aneurysm (mellkasiaorta-aneurysma)

\section{Megbeszélés}

Tanulmányunk során elsődleges célkitûzésünk az volt, hogy átfogó képet kapjunk a Magyarországon végzett mellkasi stentgraftbeültetések rövid távú perioperatív adatairól, valamint az eljárás hosszú távú eredményeiról. $\mathrm{Az}$ adatok beküldése folyamatos kommunikációt igényelt a hazánkban TEVAR-t végző intézmények munkatársaival, akik az intézmények belső adatbázisaiból tettek szert a szükséges információkra. A 2002-ben üzembe helyezett Érsebészeti Regiszter országszerte történő egységes használatával lehetőség nyílik a vizsgálatunkhoz hasonló jövőbeli kutatások hatékony kivitelezésére, ezért javasolt, hogy a Regiszterbe történő rendszeres adatbevitel a centrumokban történő érsebészeti ellátás mindennapi részét képezze $[4,5]$.

Hazánkban a vizsgált időintervallum alatt összesen 131 alkalommal került sor mellkasi stentgraft-implantációra. A mútétek száma és a beavatkozáson átesett betegeink átlagéletkora $(62,80$ év) alacsonyabb, mint a hasonló európai vizsgálatok eredményei. Egy, Svédország érsebészeti regisztereinek 1987 és 2002 között jelentett, több mint 14000 esetből származó adatait feldolgozó tanulmány során a mellkasiaorta-aneurysmában vagy -dissectióban szenvedő betegek átlagéletkora $70( \pm 12$ SD) év volt [6]. A vizsgálatunkban szereplő betegek átlagéletkora a fiatal, traumás aortasérüléseken átesett betegek életkorát is magában foglalja, ez magyarázza hazánkban az alacsonyabb értéket és a szélesebb szórást. Adataink korrelációt mutatnak a MAÉT Érsebészeti Regiszter 2013-as eredményeivel: ez az aortamütétek mellett a nyaki verőérmütétek és az alsó végtagi verőérmütétek adatait is feldol- 
gozta, s az akkor vizsgált érmútétekben szintén a 60-70 éves korcsoport volt a leginkább érintett [7].

Figyelemre méltó adat a betegek anamnézisében szereplő cukorbetegség aránya, mely nem haladja meg a 13,74\%-ot. Az érték alátámasztja, hogy a hasi aortaaneurysmák kialakulását és progresszióját ismerten gátló diabetes mellitus ugyanazon molekuláris patobiokémiai mechanizmussal a mellkasiaorta-aneurysmák kialakulását is negatívan befolyásolja, ez eredményezheti a tanulmányunkban szereplő cukorbetegek alacsony arányát [8].

Az akut beavatkozások aránya 25,19\% volt, azaz minden negyedik, Magyarországon elvégzett TEVAR akut indikációval történt. Fontos kiemelni, hogy az aorta endovascularis helyreállítása sürgető eseteknél is személyre szabott, precíz preoperatív tervezést igényel [9, 10], ezért az eljárást végző centrumokban szükség van az ezt megalapozó, akut esetekben is mindenkor elérhető logisztikai háttérre.

A TEVAR alkalmazásának javallatai tekintetében szembetűnő, hogy hazánkban a beavatkozást igénylő betegek majdnem kétharmada $(64,89 \%)$ mellkasiaortaaneurysma (ThAA) miatt került mútétre. Az adatok mutatják, hogy az aneurysma miatt végzett mellkasi stentgraftbeültetések legnagyobb részében a mütét elektív volt, és csak az esetek 16,47\%-ában állt fenn az aorta rupturája, mely a rövid távú halálozás szempontjából lényegesen magasabb rizikójú állapotot jelent.

A ThAA után a második leggyakoribb, TEVAR-t indokló betegség a komplikált Stanford B típusú aortadissectio. Szembetűnő, hogy e kórkép esetén jóval magasabb az akut beavatkozások aránya $(73,91 \%)$, mivel a deszcendens aortára lokalizálódó aortadissectio akkor képez mütéti indikációt, ha az akutan, komplikációkkal jelentkezik, vagy olyan esetben, amikor egy krónikus, nem komplikált aortadissectio hevenyen progrediálva szövődményessé válik [3, 11-13].

A mellkasi aorta tompa traumája a beavatkozások 6,87\%-át indikálta a vizsgált időszakban. E ritka, ám fiatalokat is érintő és gyakran életveszélyes állapotot okozó kórkép első választandó terápiája a TEVAR, éppúgy, mint a fent említett ThAA és komplikált B típusú aortadissectio esetében [13-15].

Az eddig említett kórképek mellett a vizsgált esetek 10,69\%-ában egyéb ok indikálta a mellkasi stentgraftbeültetést. Az indikáció ebben a csoportban a legtöbb esetben a korábbi stentgraftbeültetések hosszú távú szövődményeként megjelent endoleak volt, mely reoperációt igényelt. Fontos ennek kapcsán megjegyezni, hogy a TEVAR-on átesett betegek utánkövetése, rendszeres posztoperatív kontrollja CT-angiográfia alkalmazásával kiemelt fontosságú e szövődmények korai észlelésének és kezelésének érdekében [16].

A beavatkozások 26,72\%-ában kiegészítő revascularisatiós mútétet végeztek a supraaorticus ágakon (debranching). Erre azért van szükség, mert például ThAA miatt végzett TEVAR során a morfológia következtében egy vagy több supraaorticus ág lefedése válhat szükséges- sé. A leggyakrabban a bal arteria subclavia érintett, és számos esetben lefedésre kerül, mert akut beavatkozásoknál a legtöbbször nincs lehetőség revascularisatióra. Elektív beavatkozások végzésekor viszont törekedni kell a lehető legtökéletesebb revascularisatióra, mert csupán a bal arteria subclavia eredésének lefedése is neurológiai szövődményekhez (gerincvelői ischaemia) vagy felső végtagi ischaemiához vezethet. Erre lehetőséget biztosít a preoperatívan, külön ülésben elvégzett debranching mütét vagy a nyitott sebészi beavatkozást elkerülhetővé tevő, világszerte egyre nagyobb teret nyeró új endovascularis eljárások, melyek biztosítják a lefedett supraaorticus ágak perfúzióját (például fenesztrált stentgraftok, chimney technika, scallop technika) [17-19].

A mütétek kapcsán elszenvedett stroke $(4,58 \%)$ és a rövid távú, 30 napos mortalitás $(9,92 \%)$ értékeit összehasonlítva a European Society for Vascular Surgery (ESVS) 2017-es guideline-jával megfigyelhető egyrészrôl, hogy a posztoperatív stroke incidenciája az európai átlagnál $(5,4 \%)$ alacsonyabb volt, míg a rövid távú mortalitás megközelíti az európai átlagot, mely ThAA-nál $5,57 \%$, aortadissectiónál pedig 2,6-9,8\% közé tehető. Másrészről szembetünik, hogy európai adatok szerint a TEVAR mind a rövid távú halálozás, mind a posztoperatív stroke incidenciája szempontjából előnyösebb eljárásnak mondható, mint a nyitott mellkasiaorta-sebészeti eljárások, melyek esetén a posztoperatív stroke incidenciája eléri a 14\%-ot, a rövid távú mortalitás pedig ThAAnál 16,5\%, míg aortadissectiós esetekben 25-50\% [13]. A TEVAR-t a nyitott sebészi eljárásokkal összehasonlító hazai adatok jelenleg még nem állnak rendelkezésünkre.

A perioperatív szakban bekövetkezett bélischaemia $(2,29 \%)$, illetve a szükségessé vált vesepótló kezelés $(1,53 \%)$ alacsony incidenciája arra vezethető vissza, hogy a vizsgált időszakban történt beavatkozások során nem került sor a zsigeri ágak, illetve a veseartériák stentgrafttal történő lefedésére. Azon ritka esetekben, amikor primer és szekunder beavatkozások során szükségessé vált a thoracoabdominalis átmenet rövid szakaszú lefedése, a truncus coeliacus perfúzióját fedett stentimplantációval, illetve scalloped stentgraft alkalmazásával sikerült fenntartani. Veseartériák eszközös lefedésére nem volt példa mellkasi beavatkozások során. Az említett szövődmények tehát nem a mütétek következményei, hanem a beavatkozást indikáló kórképek következményei voltak (malperfúziós szindróma B típusú dissectióban). Hazai adataink hasonló arányokat mutatnak az elérhető nemzetközi irodalomban leírtakhoz, ahol e két ritka szövődmény előfordulása $5 \%$ alatti $[20,21]$.

Az 5 éves halálozás 16,03\%-ot ért el. Az utánkövetés esetenkénti pontatlansága, illetve a betegekról rendelkezésre álló korlátozott mennyiségú hosszú távú posztoperatív információ limitálta adatgyüjtésünk precizitását. Ennek következtében nem ítélhető meg pontosan, hogy az első 30 posztoperatív nap és az utánkövetés vége között elhunyt betegek esetében a fennálló aortabetegség volt-e a halál oka. 


\section{Következtetések}

Az endovascularis stentgraftbeültetés megbízható, eredményes módja a mellkasiaorta-betegségek korszerű kezelésének. Az eljárás hatékonyságát bizonyító, nagy számban megjelent nemzetközi eredmények mellett hazai adatok is alátámasztják az endovascularis intervenció előnyeit a hagyományosan alkalmazott nyitott sebészi eljárásokkal szemben.

A módszer további elterjedésének alappillére lenne az aortabetegségek magyarországi érsebészeti ellátásának magas progresszivitási szintû centrumokba történő átszervezése. Emellett a költséges mútéti eljárás finanszírozásának optimalizálására van szükség, mely költség azonban bőségesen megtérül a rövidebb intenzív osztályos és kórházi ápolási időnek és a betegek korábbi munkába állásának köszönhetően.

A sokszor akutan végzett beavatkozások kivitelezése összehangolt logisztikai feladatot jelent, emellett multidiszciplináris együttmúködésre van szükség az érsebészet és társszakmái között annak érdekében, hogy betegeink a jelenleg elérhető legmagasabb szintű ellátásban részesülhessenek.

Anyagi támogatás: A közlemény megírása, illetve a kapcsolódó kutatómunka anyagi támogatásban nem részesült.

Szerzői munkamegosztás: F. D. M., Sz. Z.: A vizsgálat és a közlemény felépítésének kigondolása, az irodalmi háttér áttekintése, az adatok feldolgozása és rendszerezése, a statisztikai számítások értékelése, a cikk szövegének megfogalmazása. F. G., V. G., J. Gy., V. R., K. Zs.: Adatok gyűjtése, feldolgozása és jelentése. K. M.: Statisztikai elemzés. A közlemény végleges változatát valamennyi szerző elolvasta és jóváhagyta.

Érdekeltségek: A szerzőknek nincsenek érdekeltségeik.

\section{Irodalom}

[1] Dake MD, Miller DC, Semba CP, et al. Transluminal placement of endovascular stent-grafts for the treatment of descending thoracic aortic aneurysms. N Engl J Med. 1994; 331: 1729-1734.

[2] Volodos NL, Shekhanin VE, Karpovich IP, et al. A self-fixing synthetic blood vessel endoprosthesis. Vestn Khir Im I I Grek. 1986; 137: 123-125.

[3] Grabenwöger M, Alfonso F, Bachet J, et al. Thoracic Endovascular Aortic Repair (TEVAR) for the treatment of aortic diseases: a position statement from the European Association for CardioThoracic Surgery (EACTS) and the European Society of Cardiology (ESC), in collaboration with the European Association of Percutaneous Cardiovascular Interventions (EAPCI). Eur J Cardiothorac Surg. 2012; 42: 17-24

[4] Hidi L, Menyhei G, Kováts T, et al. Report of the Hungarian Vascular Registry's data of infrarenal aortic aneurysms (20102014). [Magyarországon végzett infrarenalis aortaaneurysmamútétek eredményei az Érsebészeti Regiszter adatai alapján (2010-2014).] Orv Hetil. 2015; 156: 1991-2002. [Hungarian]
[5] Menyhei G, Simó G, Szeberin Z, et al. Establishment and func tioning of the Vascular Registry in Hungary. [Az Érsebészeti Regiszter múködtetése során szerzett tapasztalatok.] Orv Hetil. 2014; 155: 755-760. [Hungarian]

[6] Olsson C, Thelin S, Ståhle E. Thoracic aortic aneurysm and dissection: increasing prevalence and improved outcomes reported in a nationwide population-based study of more than 14,000 cases from 1987 to 2002. Circulation 2006; 114: 2611-2618.

[7] Szeberin Z, Hidi L, Kováts T, et al. Report of the 2013 data of the Hungarian Vascular Registry. [Az Érsebészeti Regiszter 2013-as adatainak elemzése.] Magy Seb. 2014; 67: 362-371. [Hungarian]

[8] Pafili K, Gouni-Berthold I, Papanas N, et al. Abdominal aortic aneurysms and diabetes mellitus. J Diabetes Complications 2015; 29: 1330-1336.

[9] Csobay-Novák Cs, Fontanini DM, Szilágyi BR, et al. Thoracic aortic strain can affect endograft sizing in young patients. J Vasc Surg. 2015; 62: 1479-1484.

[10] Parodi J, Berguer R, Carrascosa P, et al. Sources of error in the measurement of aortic diameter in computed tomography scans. J Vasc Surg. 2014; 59: 74-79.

[11] Dake MD, Kato N, Mitchell RS, et al. Endovascular stent-graft placement for the treatment of acute aortic dissection. N Engl J Med. 1999; 340: 1546-1552.

[12] Erbel R, Aboyans V, Boileau C, et al. 2014 ESC Guidelines on the diagnosis and treatment of aortic diseases: Document covering acute and chronic aortic diseases of the thoracic and abdominal aorta of the adult. The Task Force for the Diagnosis and Treatment of Aortic Diseases of the European Society of Cardiology (ESC). Eur Heart J. 2014; 35: 2873-2926.

[13] Riambau V, Böckler D, Brunkwall J, et al. Editor's Choice Management of Descending Thoracic Aorta Diseases - Clinical Practice Guidelines of the European Society for Vascular Surgery (ESVS). Eur J Vasc Endovasc Surg. 2017; 53: 4-52.

[14] Mihály Zs, Banga P, Szatai L, et al. Endovascular treatment of blunt thoracic aortic injuries. [Tompa trauma okozta mellkasi aortasérülések endovascularis ellátása.] Magy Seb. 2017; 70: 13-17. [Hungarian]

[15] Dzsinich Cs, Zsíros L, Vallus G et al. Blunt trauma of the thoracic aorta - treatment options, results. [A mellkasi aorta tompa sérülése - kezelési taktika, eredmények.] Magy Seb. 2015; 68: $155-166$.

[16] Stavropoulos SW, Carpenter JP. Postoperative imaging surveillance and endoleak management after endovascular repair of thoracic aortic aneurysms. J Vasc Surg. 2006; 43(Suppl): A89-A93.

[17] Cooper DG, Walsh SR, Sadat U. Neurological complications after left subclavian artery coverage during thoracic endovascular aortic repair: a systematic review and meta-analysis. J Vasc Surg. 2009; 49: 1594-1601.

[18] Criado FJ, McKendrick C, Criado FR. Technical solutions for common problems in TEVAR: managing access and aortic branches. J Endovasc Ther. 2009; 16(Suppl 1): 63-79.

[19] Szeberin Z, Nemes B, Csobay-Novák Cs, et al. Proximal scalloped custom-made Relay ${ }^{\circledR}$ stent graft in chronic type B dissection: endovascular repair in a drug abuser patient. Interv Med Appl Sci. 2016; 8: 37-40.

[20] Abraham CZ, Chuter TA, Reilly LM, et al. Abdominal aortic aneurysm repair with the Zenith stent graft: short to midterm results. J Vasc Surg. 2002; 36: 217-224.

[21] Szeto WY, McGarvey M, Pochettino A. Results of a new surgical paradigm: endovascular repair for acute complicated type B aortic dissection. Ann Thorac Surg. 2008; 86: 87-94.

(Fontanini Daniele Mariastefano dr., Budapest, Mészáros u. 60/C, 1016 e-mail: fontanini.med@gmail.com) 